\title{
Representation of Power Relationships in The Kite Runner
}

\author{
Muhammad Asghar Malik \\ Government Postgraduate College \\ Samanabad,
}

Faisalabad, Pakistan

\author{
Ghulam Murtaza \\ Government College University, \\ Faisalabad, Pakistan
}

\author{
Kazim Shah \\ Government College University, \\ Faisalabad, Pakistan
}

\begin{abstract}
The purpose of the present research was to analyze the linguistic manipulation in the novel, The Kite Runner (2003), according to the agenda of CDA (Critical Discourse Analysis). The researchers employed Huckin's analytic tools of CDA to make it clear how the author manipulated the text in favour of his objectives. It was analyzed how the social relations, identity, knowledge, and power were constructed through the use of linguistic devices in the text of the novel. The results of the present research revealed that the writer used specific linguistic devices to influence the readers to make them accept ideological message contained in the text. He used the text as a tool of propaganda in favour of the Western Agenda in Afghanistan. He employed linguistic manipulation as a powerful instrument for the construction of his version of reality. This study is an effort tounfold power relations, dominance, oppression, repression, and marginalization in The Kite Runner. It will help the readers in decoding the text manipulation by applying CDA.
\end{abstract}

Keywords: The Kite Runner, text interpretation, CDA, power relations, propaganda, critical thinking

\section{Introduction}

In the present research, the text of Khaled Hosseini's novel, The Kite Runner (2003), was analyzed according to the agenda of CDA (Critical Discourse Analysis). This novel wielded the foremost impact on millions of people across America and abroad. The present research attempted to unravel the power behind the text of the novel. It is an effort to explore what actually the writer communicated to the readers. For this purpose, the authors of this paper examined the social and political context in which the text of the novel was produced (Fairclough, 1995a) keeping in view the current issues of the time, like Islamic fundamentalism and Taliban. The authors investigated whether Hosseini's novel reflects text manipulation to illustrate the atrocities committed by the Taliban, as an instrument of propaganda.

The Kite Runner received numerous positive and negative reviews (Al-Sudeary, 2007; Edwards, 2009; Lidyawati, 2010; Luckhardt, 2010). However, linguistic analysis of the text of the novel was the area which was yet to be explored. The authors of this paper analyzed the linguistic manipulation which Hosseini used to materialize his objectives to construct reality. Hosseini employed certain linguistic devices which played a vital role in exchanging ideas between the writer and the reader in natural communication (Malik, Shah, \& Mahmood,

Muhammad Asghar Malik, assistant professor, English Department, Government Postgraduate College Samanabad. 
2013). These devices were designed to control the ebb and flow of knowledge, belief, narration, and assertion during both planned and unplanned discourse.Instead of employing conventional tools of stylistics and pragmatics (Widdowson, 1975; Iwamoto, 2002), the linguistic analysis of the text of the novel was conducted with reference to CDA (Huckin, 1997).

By using analytic tools of CDA, it was made visible the way in which the novel and its discourse shaped the mind of the reader. It was analyzed how the choice of specific linguistic structures influenced the readers and made them receive ideological message (Guerin, 2007) conveyed in the text of The Kite Runner. The authors also analyzed why The Kite Runner attracted so powerfully the American readers.

The focus of the present study was on how social relations, identity, knowledge, and power were constructed through text manipulation in The Kite Runner. By using Huckin's (1997) analytic tools of CDA, it was analyzed how the writer of the novel influenced the cognitive structure of the readers (Van Dijk, 2006). For the text interpretation, the insight was sought from the works of major Critical Discourse Analysts (Fairclough, 1992, 1995a, 1995b; Wodak, 2006; Van Dijk, 2005, 2006; Lakoff \& Johnson, 1980).

CDA is an electric approach for the data analysis. It should not be considered theory. It revealed the techniques which the writer used to influence cognitive structure of the readers. For text analysis, the chief assumption of CDA that makes the approach different from that of others is that it decodes not only propositional meaning of the text but also its ideological assumptions. The writer chooses specific linguistic structures to influence the readers in order to make them receive the ideological message conveyed in the text. Sheyholislami (2001) thought that text is not arbitrary. It is purposeful whether the choices are conscious or unconscious. Fairclough (1995a) argued that people exert power through conversation. Foucault (1989) considered power as a prevalent force which establishes symmetrical relationships. It prevails over the entire society and is not controlled by any particular group. But, contrary to this, Fairclough (1995a) believed in the relationship of power as asymmetrical, unequal, and empowering. It belongs to a particular group or class.

Van Dijk (2006) thought that CDA analysts must have a clear socio-political position. Their works are based on political criticism of those who are responsible for the production of ascendency and social inequalities. They discuss elite groups who are in power, ordain social inequalities and injustices, continue and legitimize them. On the basis of his interdisciplinary attitude, he labels his methodology as socio-cognitive discourse analysis. Wodak (2006) considered written and spoken language as a form of social behaviour. She acknowledged the intricacy of the relationship between language and society. ZHAO (2011) said that CDA not only describes and explains texts but also helps to root out a particular kind of delusion. He believed that texts, as elements of social events, bring about changes in the society. Guerin (2007) also realized the importance of social context for the study of linguistic devices. He favoured the ways to integrate linguistic and social analysis.

The present study will not only develop an awareness of forms of language but also explore a wider range of language impacts in our daily lives. It provides an analytical way of learning about Afghan history and culture in the context of story. In the present research, Huckin's (1997) analytic tools of CDA were used for the text interpretation of the novel, The Kite Runner. The authors of this paper selected Huckin's (1997) analytic tools for text analysis, because they provide a framework of text analysis according to the agenda of CDA. Moreover, they provide data which were used both at macro level to reveal the "big picture" of asymmetrical power relationship and at micro level to analyze the role of the linguistic devices in the novel. In this research, the data were 
collected from the detailed analysis of the text of the said novel to answer the following research questions of the present research: (1) Does the writer use the text of the novel as a tool of propaganda in the novel?; (2) Does the writer maneuver the facts for the propagation of the Western angle of interpretation of the situation in Afghanistan in the novel?; (3) How do the dominant forces construct versions of reality in favour of their interests in the novel?; (4) What are the objectives of the writer in representing ethnicity in the novel, The Kite Runner?; and (5) What are the levels of power relationship in The Kite Runner?.

This study will help in developing critical thinking of the readers by enabling them to decode text manipulation. The linguistic analysis will benefit CDA practitioners to analyze their existing problems and tackle with them in order to introduce the way for better way of teaching CDA. The findings of this study provide them with an insight to text analysis. This research is also an attempt to highlight the scope of CDA for the text analysis of the novel. It helps to know how CDA techniques can assist in the formulation of appropriate strategies for reading. This research invites researchers to explore new horizons of text analysis by using agenda of CDA. It motivates related researches, for instance, applying CDA to the texts of poetry, drama, and fiction.

\section{Methodology}

In the present research, the authors attempted to disclose the strategy which the writer employed to manipulate the text of the novel, The Kite Runner, in favour of his objectives. The research problem is to investigate how the writer employed the linguistic devices to influence the opinion of the readers by constructing a particular reality in the said novel.

In the present research, Huckin's (1997) analytic tools of CDA were used for the text interpretation of The Kite Runner. The text analysis was conducted at three levels: the text as a whole, a sentence, and a word. The salient features of the procedure of the present research are mentioned as under.

\section{The Text as a Whole}

At the first stage, the researchers analyzed the text of the The Kite Runner at macro level to explore how the writer of the said novel has manipulated information for his objectives. Following techniques were used for macro analysis:

(1) The genre of the text under analysis was analyzed in order to observe that the text of the novel conforms to its type or the writer has included features of other genres to fulfill his own purposes. This genre-orientation helped to know how to manipulate a genre and how to go beyond its normal boundaries to produce special effects.

(2) Framing of text production was analyzed. It was evaluated how the content of the text has been presented and what sort of perspective (angle, slant) the writer has taken.

(3) The techniques of foregrounding and backgrounding were analyzed to explore how they have been used to emphasize or de-emphasize certain concepts in the text under analysis.

(4) The technique of omission was analyzed to explore how the writer has used to keep certain things completely out of a text. If the writer does not discuss some particular point, it often will not even enter the reader's mind. Thus, it is not subjected to reader's scrutiny.

(5) The technique of presupposition was analyzed to explore how the writer has used to manipulate readers. Ideas are presented in such a way as to be accepted without questioning. 
(6) Another form of presuppositions is insinuations. It is used in the comments of a suggestive nature and not directly indicated by the writer.

\section{Sentence Level Analysis}

After the analysis of the genre and framing of the text, the research proceeded to the sentence level as mentioned under:

(1) Topicalization: It is a sort of foregrounding at the sentence level. This type of analysis was conducted to reveal the objective of the writer's decision to put something in the topic position. This linguistic device is employed to make readers notice certain pieces of information as more important than others.

(2) Deletion or omission of agents: The focus is on the victims and not on those guilty of the crime. Agent-deletion takes place most often through the use of passive verbs and nominalization.

(3) Presupposition: Presupposition was analyzed at the sentence level.

\section{Words and Phrases Level Analysis}

The research was also conducted at micro level by employing the following techniques:

(1) Connotations: CDA of the text was conducted on the level of individual words to analyze certain connotations that they carry with themselves.

(2) Register: This type of analysis was conducted to reveal the text's level of formality or informality. It also points out its degree of technicality and its subject field.

(3) The quantitative methodology of Corpus linguistics was used as a supplement to determine the frequencies of certain lexical items.

\section{Discussion}

In the present research, the text of the novel, The Kite Runner, was analyzed, at macro and micro level, by using Huckin's (1997) analytic tools of CDA. The analysis was conducted on three levels: the text as a whole, a sentence, and a word. In this research, the data were collected from the detailed analysis of linguistic devices of the text of the said novel to answer the research questions of the present research.

\section{Text Manipulation and Linguistic Devices}

CDA is an effective approach for the study of the text. It studies language as a form of social practice and explores the ways how social and political domination are visible in the text (Fairclough, 1989). The writer, Khaled Hosseini, employed the linguistic devices as a powerful tool to manipulate the text in favour of his objectives. His effective use of linguistic devices acted as a catalyst to stimulate the reader's emotions and curiosity about ethnicity.

It is notable that the main readers of The Kite Runner are not the Afghans. The novel clicks so powerfully with American readers. It pays particular attention to the "hot topics" such as extremism, fundamentalism, Taliban, and women's rights in Afghanistan. The writer introduces his readers with life in Afghanistan by explaining some basic facts with a particular tilt of mind. After the analysis, it has been found that the writer of the novel, Khaled Hosseini, uses the linguistic devices of foregrounding, backgrounding, presupposition, and omission to frame the contents of the text in favour of his objectives. He uses the characters of Baba, Amir, Ali, and Hassan to frame economic, ethnic, and religious divisions in Afghanistan. Baba and Amir, for example, are 
rich and live in a large house, while Ali and Hassan are poor and live in a small quarter on Baba's property. Baba and Amir are both physically fit, but Ali and Hassan both suffer from problems of physical deformation. Furthermore, Baba and Amir represent the Pashtun population, whereas Ali and Hassan represent Hazara minority who are the victim of racism in Afghanistan. Like most Pashtuns, Baba, and Amir represent Sunni Muslim, while Ali and Hassan, like most Hazaras represent Shia Muslim.

The Kite Runner deals with the issue of ethnic discrimination in Afghanistan. There is a particular example of the relationship between Pashtuns and Hazaras. The writer presents another frame of division between Islamic fundamentalists, like Amir's teacher, Mullah Fatiullah Khan, and liberal Afghans like Baba. Baba's words, in Chapter 3, predict the future takeover of Afghanistan by the orthodox fundamentalists, the Taliban. Baba says: “God help us all if Afghanistan ever falls into their hands” (Hosseini, 2003, p. 8). The writer uses extremely harsh words for Mullah Fatiullah Khan and those like him and declares them “self-righteous monkeys” (Hosseini, 2003, p. 17).

The writer uses the first-person point of view in the novel. He makes readers feel as though they are experiencing narrator's personal feeling and thoughts about certain people or particular scenes. For example, when Amir attends the inaugural ceremony of his father's orphanage, he says that he "wished they'd all died along with their parents” (Hosseini, 2003, p. 19), and this personal emotion clearly reveals his strong desire for his father's love and attention. The reader is made to feel that his thoughts are flowing directly through the characters brain. It seems that the character and the reader are thinking in the same direction. The first-person point of view deeply connects the emotions of the characters and the readers. In contrast, the third-person point of view lets the writer keep distance and achieve some measure of objectivity.

Another effective linguistic device that the author employs in the novel is the use of the register of Farsi words (Huckin, 1997). Throughout the entire novel, Farsi is woven in the plot naturally, especially in conversations. For example, Amir calls his father "Baba (12 times) or Baba Jan (18 times)" instead of "dad” or "father", but the reader is able to interpret these words by context. The words such as "Inshallah" (36 times) or "Naan" (29 times) have also been used. It appears more natural to use Farsi in conversation. It enhances informal level of the text (Huckin, 1997). This technique adds a realistic touch to the text. Furthermore, most of the events occur in a foreign country where English is not the characters' native language. Therefore, using Farsi in conversation seems more natural. As a result, this device gives the reader a much more vivid experience, as though the reader has participated in the scenes and met the characters themselves.

In his novel, the writer has employed the linguistic device of omission or deletion to construct a particular realty with a particular objective of representing ethnicity. The writer has framed the character of Assef as an embodiment of evil by eliminating every positive trait of a human being. He is the main "Antagonist" of the novel. Ironically, he has been presented as a mixed product—his father is Afghan and his mother is German. It seems very awkward that an individual of mixed origin has been presented as an advocate of Pashtun dominance over the Hazara. As a teenager, Assef is a bully and Amir describes him as a "sociopath". As a child, he commits the heinous action of raping Hassan and he gives Amir a biography of "Adolf Hitler” as a birthday present. As an adult, he joins the Taliban and has become like his ideal, Adolf Hitler. He feels pleasure in murdering innocent people in the name of purity and supremacy. The writer presents Assef as a chain of heinous crimes. He raped Hassan in childhood, and he is now raping and degrading Hassan's son. 


\section{A Tool of Propaganda}

Propaganda means to spread ideas or rumors to favour or disfavour a person or group of people. In the novel, The Kite Runner, the writer paints a vivid picture of the Taliban as violent bodies responsible for all the wrongs in Afghanis. Assef appears in pre-Taliban times as a symbol of evil and then emerges as a leading Talib.

Before the regime of the Taliban, Assef commits the crime of rape, and as a leader of the Taliban, compels Sohrab to dance to music for his enjoyment but the Taliban has banned dancing and listening to music. In Chapter 22, Amir criticizes Taliban by saying: “I guessed music wasn't sinful as long as it played to Taliban ears” (Hosseini, 2003, p. 141). The writer shows that the Taliban's oppression of the Hazaras and the Shiites is not new. It is a greatly intensified outcome of long-held discrimination. The writer frames the characters of the Taliban and the Hazara in order to point out the nature of their power relationship as asymmetrical, unequal and empowering (Fairclough, 1995b).

The writer depicts one-dimensional characterization of the Taliban as stereotyped characters. He presents them as inhumane and tyrannical. The novel has been written with the technique of first-person viewpoint. Amir is the narrator for 24 chapters, while Rahim Khan narrates the events of the past in only one chapter, Chapter 16. Both narrators express only their own personal experiences, and both paint a terrible picture of atrocities of Taliban. Decades later, Hassan's rape is echoed by Sohrab's rape symbolically. One of the most striking references is of the stoning at Ghazi Stadium. This event also symbolizes the devastation of Afghanistan as a whole, like the rapes of Hassan and Sohrab. Another very fierce event is Amir's fight with Assef. In Chapter 21, the reference of "Mullah Nasruddin" is to laugh at plans of the Taliban.

The writer, with the help of linguistic devices, manipulates the text of the novel for the Propagation of the Western angle of the Afghan issue. It is an effort to influence the readers and to justify the Western Agenda of international commitment in Afghanistan. In the last scene of the novel, Sohrab's faint smile is an indication that he is secure and happy with his new guardians (Van Dijk, 2005, 2006).

The writer also uses powerful and multi-layered imagery with rich meanings. For example, Sohrab hits Assef with slingshot fire. It is an appropriate image that shows the triumph of the weak and depressed over the high and mighty.

In Chapter 11, after the arrival of Amir and Baba in America, Amir explains that Baba loved "the idea of America” very much. He believes that the only valuable countries are America, Israel, and Britain. Even though his support of Israel drew allegations of his being anti-Islam from other Afghanis. Baba says:

“There are only three real men in this world, Amir,” he'd say. He’d count them off on his fingers: America the brash savior, Britain, and Israel. "The rest of them—" he used to wave his hand and make a phht sound "—they're like gossiping old women”. (Hosseini, 2003, p. 63)

In Chapter 21, the writer presents a vivid picture of fundamentalism, extremism, and intolerance of the Taliban. Amir attends a soccer match at Ghazi Stadium. There is entirely different scene. The lush green playing field has now turned into barren field with two deep holes behind the goalpost. The Taliban walk up and down the lanes. They whip anyone who makes too much noise. During halftime, Amir knows the shocking reason for the two deep holes in the ground. They are to be the graves of two accused adulterers. They shall be stoned in front of thousands of the people. A Talib announces to the crowd that the "will of Allah and the word of the Prophet 
Muhammad" said death by stoning is a just punishment for adulterers. As Amir listens to this distortion of Islam, he recalls the words of Baba: "God help us all if Afghanistan ever falls into their hands" (Hosseini, 2003, p. 136).

By narrating this incident, the writer makes the point that the Taliban are responsible for social inequalities and injustices. They continue and legitimize their activities in the name of Islam (Van Dijk, 2005).

The writer has tried to establish the idea that the United States is an escape route from all of the problems. He feels that the United States is like an outlet from injustice, cruelty, and ethnicity. His attitude is negative throughout the whole story and uses the escape of Amir and Baba to America as a symbol of change and a rout of emancipation. The writer is trying to justify that only America can play role in the line of changing, amending, and removing inequalities from the Afghan society (Van Dijk, 2006).

The writer very skillfully talks about dominant American culture in the country. Amir and Hassan like the Western movies, American actors, especially John Wayne and Charles Bronson. They watch movies dubbed into Farsi. The boys spend their money on imported snacks like rosewater ice cream and pistachios. Baba drives a black Ford Mustang, which is the same car that the actor Steve McQueen has used in the American movie Bullitt. On the other side, Assef never speaks of these things. He talks about purity of Afghanistan. Assef and his fellows demand not only ethnic purity but also cultural purity. The purpose is domination of a pure Pashtun people and culture in Afghanistan. As a consequence, the influence of American culture in Afghanistan will be eliminated, almost entirely, during the period that Amir calls the end of Afghanistan.

\section{Versions of Reality and Power Relationship}

In the present research, the text of The Kite Runner can be explained through CDA to explore how the levels of power, dominance, inequality, and bias sources have been initiated, maintained, and reproduced. In the novel, The Kite Runner (Van Dijk, 2006), one of the best examples of oppression, repression, and marginalization (Luke, 1997) is Hassan's rape in the passage on pages 76 to 77 . The power struggle in this passage is established on many levels. The Assef's domination of Hassan is the most obvious level. There are, however, numerous instances of a power relationship in the passage, e.g., between Amir and Hassan, between the Mullah and the sheep, and between Amir and himself. The writer compares the facial expression of Hassan to that of a lamb in "saw the resignation in. It was a look I had seen before. It was the look of the lamb” (Hosseini, 2003, p. 76). The same symbol of lamb is later explained, through Amir's flashback as a ceremonial sacrifice made on Eid Al-Adha. This use of metaphors and symbolism makes the language effective and admirable (Lakoff \& Johnson, 1980). Hassan is entirely powerless against Assef. There is another example of the power struggle between Amir and Hassan. Amir is constantly struggling for his father's love. He feels that Hassan is standing in his way. In the end of the passage, Amir says:

I actually aspired to cowardice, because the real reason I was running, was that Asseff was right. Nothing was free in this world. Maybe Hassan was the price I had to pay, the lamb I had to slay to win Baba. Was it a fair price? The answer floated to my conscious mind before I could thwart it: "He was just a Hazara, was not he? (Hosseini, 2003, p. 77)

It is clear that Baba's love is a form of power and Amir is willing to gain this power at any cost even by losing his friend.

\section{Objectives of the Writer}

In the text of the novel, the writer himself describes, directly or indirectly, his objective of writing the novel, The Kite Runner. Some of the references are following: 
(1) In Chapter 19, through the mouth of Wahid, the writer reveals his objectives in the words: "Tell the rest of the world what the Taliban are doing to [Afghanistan]" (Hosseini, 2003, p. 118).

(2) The reference to sexual violence against a member of one ethnic group-the Hazara-at the thematic position of the novel indicates the objective of the writer to highlight the frame of ethnicity in the very beginning of the novel. Foregrounding of ethnicity shows ethnic orientation of the text.

(3) The writer employs the linguistic device of deletion/omission for the depiction of certain characters in order to influence the mind of the readers. By doing so, he makes the readers see a particular reality through the glasses of the writer. From beginning to the end, the writer frames and presents an entirely negative, heinous, and cruel picture of the Taliban: (a) In Chapter 3, the writer begins to develop the negative impression of Mullah, Taliban, and Islamic convictions by making extensive use of foreshadowing. For instance, Baba's statement, which anticipates the Taliban's takeover decades later: "God help us all if Afghanistan ever falls into their hands" (Hosseini, 2003, p. 8); (b) In Chapters 16-17, the writer also uses some incidents of abuses of women to paint the distorted image of the Taliban. The Taliban has enforced strict rules of dress for men and women; and (c) Soccer players have to wear pants, and loud cheering is not allowed at games. However, worst of all is the fierceness that the Taliban show in the general population.

(4) The hidden objective of the writer is to paint a distorted picture of Afghan culture by maneuvering facts and highlighting the ethnic tensions between the Pashtun and the Hazara. By rescuing Sohrab, the writer tries to justify American task to rescue the oppressed people of Afghanistan (Fairclough, 1995a).

(5) Another objective of the writer is to make the readers acknowledge the American supremacy in the world. In Chapter 21, the writer tries to establish American supremacy of technology and culture. Before going to bed, Farid tells stories about fighting the Soviets, while Amir tells Farid about American services, such as being able to enjoy over five hundred television channels.

In the novel, the foregrounding of ethnicity shows ethnic orientation of the text. The writer maneuvers the facts in order to establish that the Pashtun majority of the Taliban hatethe Hazara population. Thus, the Taliban massacred many Hazaras. They burned down their schools and houses. Assef praises the Pashtun history and relates it to that of the Nazis in Germany. This is an example of the use of linguistic device of presupposition (Huckin, 1997) by referring a remarkably accurate historical observation that the writer points out on several occasions. Khalid Hosseini is a remarkable writer and knows how to influence the readers by constructing a particular reality and make them accept a particular ideology.

\section{Conclusions}

The objective of the present study was to identify the role of the linguistic devices in the construction of the version of reality in The Kite Runner. The detailed analysis of the text of the novel, both at the macro level and the micro level, revealed that the linguistic devicesplayed significant role in linguistic manipulation. The writer manipulated the text for the construction of reality to materialize political objectives of supporting Western Agenda in Afghanistan. He used the linguistic devices of foregrounding, backgrounding, presupposition, and omission to frame the contents of the text in favour of his objectives. These linguistic devices proved an influential instrument to touch the cognitive structure of the reader. The writer maneuvered the facts for the propagation of the Western angle of interpretation of situation in Afghanistan. By way of a subtle manipulation of 
language, he successfully wielded great influence on the preconceptions, beliefs, and ideologies of the readers. The results of this study indicate that behind the apparent text of The Kite Runner, there is a careful use of linguistic devices. They are certainly the product of prior consideration and thoughtful discourse elaboration.

The writer used the language of the novel as a typical instrument of persuasion. He employed the appropriate linguistic devices according to the specific requirements of each communicative situation for the achievement of personal objectives. With the help of a subtle manipulation of language, he caused the readers to accept false claims as true assumptions. He persuaded them to favour policies contrary to their interests. Linguistic manipulation is, thus, a valuable tool in politics. It is a vital element in securing the public support which is essential not only to legitimize political policies, but also to materialize implied political objective in democratic systems. The effective use of linguistic devices is a key factor in accomplishing personal and public objectives and succeeding in public debates and negotiations.

\section{References}

Al-Sudeary, M. A. (2007). Power relations in The Kite Runner. Retrieved from http://pubcouncil.kuniv.edu.kw/ajh/home.aspx?id=8\&Root=yes\&authid=1926\#

Aubrey, T. (2009). Afghanistan meets the Amazon: Reading The Kite Runner in America. Retrieved from http://www.mlajournals.org/toc/pmla/124/1

Brown, G., \& Yule, G. (1983). Discourse analysis. Cambridge: Cambridge University Press.

Edwards, J. (2009). Expatriate literature and the problem of contested representation: The case of Khaled Hosseini's The Kite Runner. Retrieved from http://www.inter-disciplinary.net/ati/diversity/multiculturalism/mcb2/edwards\%20paper.pdf

Fairclough, N. (1989). Language and power. London: Longman.

Fairclough, N. (1992). Discourse and social change. London: Polity Press.

Fairclough, N. (1995a). Critical discourse analysis. London: Longman.

Fairclough, N. (1995b). Media discourse. London: Arnold.

Foucault, M. (1989). Archaeology of knowledge. London: Tavistock Publications.

Guerin, B. (2007). Two "linguistic devices" that require social context: Integrating social and linguistic analysis. Retrieved from http://www.nzlingsoc.org/documents/Guerin\%20devices.pdf

Hosseini, K. (2003). The kite runner. New York: Riverhead Books.

Huckin, T. N. (1997). Critical discourse analysis. Retrieved from http://eca.state.gov/education/engteaching/pubs/BR/functionalsec3_6.htm

Hudson, W. H. (1965). An introduction to the study of literature. London: George G. Harrap \& Co. Ltd..

Iwamoto, N. (2002). Stylistic and linguistic analysis of a literary text using systemic functional grammar. Retrieved from http://human.kanagawa-u.ac.jp/gakkai/publ/pdf/no162/16209.pdf

Koller, V. (2005). Critical discourse analysis and social cognition: Evidence from business media discourse. Discourse \& Society, $16(2), 199-214$.

Krishnamurthy, R. (2003). Ethnic, racial and tribal: The language of racism?. In C. R. Coulthard (Ed.), Text and practices (pp. 129-149). London and New York: Routledge.

Lakoff, G. (2004). Don't think of an elephant! Know your value and frame the debate. Vermont: Chelsea: Green Publishing.

Lakoff, G., \& Johnson, M. (1980). Metaphors we live by. Chicago: Chicago University Press.

Lidyawati, S. (2010). An analysis of main characters in Khalid Hossein's novel: The Kite Runner. Retrieved from http://repository.usu.ac.id/bitstream/123456789/13424/1/10E01043.pdf

Luckhardt, J. K. (2010). Building cultural competence through multicultural fiction. Retrieved from http://thescholarship.ecu.edu/bitstream/handle/10342/2832/Luckhardt_ecu_0600M_10140.pdf

Luke, A. (1997). Genres of power: Literacy education and the production of capital. In R. Hasan, \& G. Williams (Eds.), Literacy in society (pp. 308-338). London: Longman.

Malik, M. A., Shah, K., \& Mahmood, R. (2013). The role of linguistic devices in representing ethnicity in The Kite Runner. Retrieved from www.macrothink.org/.../ijl/article/download/3303/2777 
Meyer, M. (2001). Between theory, method, and politics: Positioning of the approaches to CDA. In R. Wodak, \& M. Meyer (Eds.), Methods of critical discourse analysis. London: Sage.

Sheyholislami, $\quad$ J. (2001). Critical discourse analysis. $\quad$ Retrieved from http-server.carleton.ca/ jsheyhol/articles/what\%20is\%20CDA.pdf

Van Dijk, T. (2005). Discourse analysis as ideology analysis. In C. Schaffner (Ed.), Language and peace (pp. 17-33). Amsterdam: Harwood Academic Publishers.

Van Dijk, T. (2006). Discourse and manipulation. Discourse and society, 17, 359-383.

Widdowson, H. (1975). Stylistics and the teaching of literature. London: Longman.

Wodak, R. (2001). What CDA is about—A summary of its history, important concepts, and its development. In R. Wodak, \& M. Meyers (Eds.), Methods of CDA (pp. 1-13). London: Sage Publications.

Wodak, R. (2003). The genesis of racist discourse in Austria since 1989. In C. R. Coulthard (Ed.), Text and practices (pp. 107-128). London and New York: Routledge.

Wodak, R. (2006). Critical linguistics and critical discourse analysis. In J. Verschueren, \& J. O. Ostman (Eds.), Handbook of pragmatics. Amsterdam: John Benjamins.

Yule, G. (1985). The study of language. Cambridge: Cambridge University Press.

ZHAO, J. (2011). Comparative critical analysis of discourse structures. Retrieved from http://ojs.academypublisher.com/index.php/tpls/article/view/3767/0 